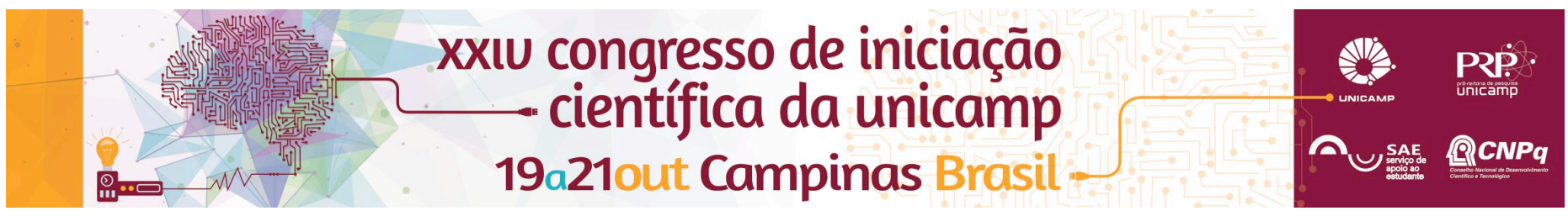

\title{
Documentários autobiográficos e a invasão do Eu
}

\author{
Paola T. P. Favaro*
}

\section{Resumo}

Esse estudo investiga os aspectos que tangem o sujeito do documentário autobiográfico, debruçando-se sobre as relações inter e intrasubjetivas do indivíduo imerso numa era narcísica, focando-se nas narrativas que os realizadores tecem de si e investigando o que motiva tais atos autobiográficos. A base teórica é aplicada na análise fílmica de três obras: Diário de uma busca (2010) de Flávia Castro, Photographic memory (2011) de Ross McElwee e Tarnation (2003)

de

John

Caouette.

\section{Palavras-chave \\ Documentário autobiográfico, documentário e família, narcisismo}

\section{Introdução}

A sociedade contemporânea se encontra acometida de moléstias psíquicas generalizadas: ansiedade, vazio interior, crescente necessidade de aprovação pública e diante de tudo isso, crença na cura através do autoconhecimento. $\mathrm{O}$ indivíduo atualmente, em maior ou menor grau, é socialmente acometido de sintomas generalizados de narcisismo ${ }^{[1]}$. Enraizado no campo cinematográfico, esse estudo parte da observação de documentários autobiográficos para melhor entender como esse quadro clínico tão social quando psíquico culmina na incursão para dentro de si próprio a partir do processo fílmico. Partindo dos três documentários autobiográfico supracitados, institui-se um processo investigativo questionando-se as motivações que impulsionam tais tentativas de melhor entender a si próprio. Debruçando-se sobre suas origens pessoais, esses cineastas capturam determinadas tensões, a partir das quais resultam processos subjetivos de narrativização, construção de auto-imagem e performance. O poder intrínseco ao dispositivo fílmico deflagra e reflete os desejos de toda uma sociedade na qual estes nos sujeitos realizadores se inscrevem: a obtenção de omnisciência e omnipotência.

\section{Resultados e Discussão}

A projeto da pesquisa em questão contava com o prazo padrão de 12 meses de duração, tendo um cronograma pensado para essa extensão. Diante da aprovação em $15^{a}$ chamada, o planejamento necessitou ser redimensionado para os 7 meses concedidos, de forma que os objetivos específicos voltados para estudo da historiografia do documentário autobiográfico e da literatura psicanalítica sobre narcisismo não puderam ser executados na abrangência inicialmente pretendida. Eles foram cumpridos na medida em que possibilitaram os demais objetivos, aqueles mais diretamente ligados às obras selecionadas. Em detrimento de uma extensa historiografia do gênero documental autobiográfico e de um debate detalhado no campo da psicanálise, a pesquisa insere a contextualização já mais diretamente nos estudos de caso e na medida em que foi possível se adquirir domínio dentro do prazo concedido. Dessa forma, esse estudo dinamizou a metodologia de alguns objetivos específicos para não deixar de cumprir com o objetivo geral incialmente proposto.

\section{Conclusões}

Tendo como cenário comum o círculo familiar, as obras selecionadas para esse estudo retratam, cada uma, as relações e tensões pessoais entre os sujeitos realizadores e seus familiares. Essa investida para dentro de si compreende consigo todo o retrato familiar justamente pois pretende-se que os conflitos advindos dali tragam ao cineasta um maior conhecimento sobre si próprio. Contudo, quando essa tentativa perpassa o dispositivo fílmico e criam-se novas relações de poder, o filme passa a ser também uma reescritura das próprias origens. O gesto autobiográfico representa uma tomada narcísica de auto reconstrução, uma tentativa de tornarse o criador omnipotente e omnisciente de si próprio.

\section{Agradecimentos}

Meus agradecimentos ao CNPq, ao PIBIC e especialmente ao Professor Marcius Freire por suas orientações Agradeço também pelos atenciosos conselhos de seu grupo grupo de mestrandas e doutorandas; Jennifer Serra, Teresa Noll Trindade, Fernanda Serradourada, Letizia Nicoli, Viviana Echávez, Andy Goode e Josy Samanta de Miranda.

${ }^{1}$ LASCH, Christopher (1983). A cultura do narcisismo: a vida americana numa era de esperanças em declínio. Rio de Janeiro, Imago. 